\begin{tabular}{c|c|c}
\hline \hline & MARINE ECOLOGY PROGRESS SERIES \\
Vol. 227: 269-273, 2002 & Mar Ecol Prog Ser & Published February 13 \\
\hline
\end{tabular}

\title{
Ancient DNA in the seagrass Posidonia oceanica
}

\author{
Raffaella Raniello, Gabriele Procaccini*
}

\author{
Stazione Zoologica ‘A. Dohrn', Laboratorio di Ecologia del Benthos, 80077 Ischia (Napoli), Italy
}

\begin{abstract}
Posidonia oceanica is a seagrass endemic to the Mediterranean, characterized by low genetic polymorphism, with potential effects on its survival and expansion. In the last 2 decades, a progressive decline of $P$. oceanica meadows was recorded. This could derive either from intrinsic characteristics of the plant or from habitat fragmentation and isolation induced by external sources of impact. P. oceanica forms large meadows whose remains can persist in the matte and in the sediment for thousands of years. In this paper we illustrate a protocol for the extraction of DNA from old remains of $P$. oceanica (between 300 and $1100 \mathrm{yr}$ old) collected in the matte and in marine sediments in order to gather information on the evolution of genetic diversity over time. We also report a first genetic analysis of old seagrass DNA using species-specific microsatellite markers.
\end{abstract}

KEY WORDS: Posidonia oceanica $\cdot$ Seagrasses $\cdot$ Matte $\cdot$ Old DNA $\cdot$ DNA extraction $\cdot$ Microsatellites Resale or republication not permitted without written consent of the publisher

\section{INTRODUCTION}

Posidonia oceanica grows in the Mediterranean Sea, along the coast of the eastern and western basins. It is a structural species and forms long-living ecosystems (Larkum et al. 1989, Mateo et al. 1997), allowing development of associated communities characterized by conspicuous species diversity (Mazzella et al. 1992). $P$. oceanica meadows prevent erosion of coastline, forming 'barrier reefs' and small coastal lagoons (Harlin et al. 1982, Hemminga \& Nieuwenhuize 1990).

Posidonia oceanica meadows are formed by horizontally growing rhizomes, which start to grow vertically when the available space is completely covered. The dense canopy thus formed acts as a sediment trap. Thus, the over-growth of horizontal and vertical rhizomes and the sediments trapped within the remaining scales and sheets form an organic structure called 'matte'. The vegetative growth is very slow, with estimated rates of vertical rhizome elongation ranging between 0.4 and $1.1 \mathrm{~cm} \mathrm{yr}^{-1}$, and horizontal elongation between 0.4 and $7.4 \mathrm{~cm} \mathrm{yr}^{-1}$ (Boudouresque \& Jeudy de Grissac 1983).

\footnotetext{
*Corresponding author. E-mail: gpro@alpha.szn.it
}

Posidonia oceanica can reproduce both sexually and clonally, and meadows can be either single clones or groups of many individuals (genets), depending on the success of sexual reproduction and seedling recruitment. A small number of genotypes was found in distinct populations (Procaccini \& Mazzella 1998, Procaccini et al. 2001a, in press), suggesting an overall low level of genetic diversity in $P$. oceanica. This could result from biological factors (i.e. long generation time, strong clonal growth and infrequent sexual reproduction) or post-glacial bottleneck effects.

Posidonia oceanica has been present in the Mediterranean Sea since the Miocene (Pérès 1985) and survived during the last glaciation in refugia from which it re-colonized the basin (Pérès 1984). It has been hypothesized that the plant had its climatic optimum around 4000 to $8000 \mathrm{yr}$ ago, not being well adapted to the present conditions of the basin (Molinier \& Picard 1952, Pérès 1984). Besides general trends of increased coastal erosion and decreased water clarity, possibly related to global climatic changes, the high impact of human communities along the coast can also account for the recorded meadow regression (Marbà et al. 1996, Short \& Wyllie-Echeverria 1996). The enhanced meadow isolation, together with the existing low genetic polymorphism and small population size found 
in P. oceanica (Procaccini et al. 2001a, in press), raises concern for the future of this species in the Mediterranean.

The status of this important resource, however, can only be assessed correctly by evaluating whether low genetic diversity in Posidonia oceanica has occurred throughout its history and has been inherited through asexual reproduction or whether it is a relatively recent phenomenon. The historical memory of $P$. oceanica genetic diversity can be sought in the DNA still present in the organic remains of rhizomes and leaf scales, preserved within the matte and other marine sediments. Hypoxia occurs within a few centimeters below the sediment surface, allowing longterm preservation of ligneous material such as rhizomes and roots (Lipkin 1979, Crouzet 1984).

Here we present an optimized protocol for DNA isolation from old Posidonia oceanica material as well as a first comparison between recent and old genotypes. Where population genetic screening of living seagrass beds allows only a tentative reconstruction of the past diversity, our approach could permit its direct reading to assess the evolutionary history of this plant and to forecast the species' fate in the Mediterranean basin. Although old DNA has been isolated and PCR-amplified in a series of plant species (e.g. Rogers \& Bendich 1985, Rollo et al. 1987, Golenberg et al. 1990, DumolinLapegue et al. 1999) this is the first time that DNA has been isolated and species-specific microsatellites amplified from old seagrass remains.

\section{MATERIALS AND METHODS}

Sample collection. Two samples were collected and included in the analysis.

Sample A was obtained from a sediment core collected $42 \mathrm{~m}$ below sea level on soft bottom not colonized by Posidonia oceanica (Procida channel, Gulf of Naples, Italy). Well-preserved vegetable remains were found at $1.25 \mathrm{~m}$ depth in the core. The sample, as determined by correlation with pyroclastic rocks of known origin and age (Carbone et al. 1984), is about 1100 yr old.

Sample B consisted of rhizome remains collected at $11 \mathrm{~m}$ depth in Lacco Ameno meadow (Ischia, Gulf of Naples), $60 \mathrm{~cm}$ below meadow level. It was taken $20 \mathrm{~cm}$ inside the canopy from the vertical front of the exposed matte, in order to minimize the possibility of collecting recent material overgrowth on the ancient remains. It was dated $300 \mathrm{yr}$ old, according to Lacco Ameno matte age estimations in Mateo et al. (1997).

Samples were washed with ethanol and distilled water, dried on absorbent paper and stored at $-20^{\circ} \mathrm{C}$ for further DNA extraction.
The DNA extraction protocol, reported in Procaccini et al. (1996), was modified due to the particular nature and age of our samples. The main problems were related to the presence of polyphenols in ligneous material and to the small amount of preserved DNA expected in the samples.

DNA extraction. The following modified method of Procaccini et al. (1996) was used:

(1) The material (0.5 to $1 \mathrm{~g}$ ) was ground into fine powder in a mortar with liquid nitrogen.

(2) The powder was transferred into a centrifuge tube containing $8 \mathrm{ml}$ of $2 \times$ CTAB extraction buffer (Doyle \& Doyle 1987) with sodium dodecyl sulfate $0.005 \%$, $\beta$-Mercaptoethanol $0.05 \%$ and polyvinylpolypyrrolidone (PVPP) $0.4 \%$ and incubated at $65^{\circ} \mathrm{C}$ for $1 \mathrm{~h}$, with occasional agitation.

(3) Samples were centrifuged in a clinical centrifuge (30 min at room temperature, $4000 \times g$ ).

(4) Supernatant was transferred into a clean centrifuge tube and submitted to a phenol:chloroform:isoamyl alcohol (25:24:1) extraction followed by 2 chloroform:isoamyl alcohol (24:1) extractions.

(5) The aqueous phase was mixed with an equal volume of isopropanol alcohol and stored overnight at $-20^{\circ} \mathrm{C}$.

(6) The solution was centrifuged $\left(30 \mathrm{~min}, 4^{\circ} \mathrm{C}, 12000\right.$ $\times g$ ) and the pellet washed with $70 \%$ ethanol.

(7) The DNA pellet was re-suspended in $40 \mu \mathrm{l}$ sterile distilled water and stored at $-20^{\circ} \mathrm{C}$.

(8) The total DNA was run on an $0.8 \%$ agarose gel and the high molecular weight region was excised from the gel and eluted with QIAEX II kit (Qiagen), following the manufacturer's instructions. The elution of chromosomal DNA from agarose gel was required for removal of contaminant polyphenols. The electrophoretic separation of polyphenols from chromosomal DNA was allowed by their fast migration in the gel (similar to 100 base pair [bp] DNA fragments). As an elution negative control, we processed a slice of agarose gel taken from a line where no samples had been loaded.

The DNA extraction protocol was also performed on 2 negative controls, both consisting of $8 \mathrm{ml}$ of the extraction buffer, 1 of which had been previously poured into the mortar used for sample grinding. Vegetable tissues and negative controls were processed at the same time.

PCR amplification of microsatellite sequences. PCR using ancient seagrass DNA was performed for 3 Posidonia oceanica microsatellite regions (Poc-5, Poc-26, Poc-45; Procaccini \& Waycott 1998). For genotype analysis, microsatellite were amplified and visualized as in Procaccini \& Waycott (1998). PCR products were also cloned and sequenced to verify correct assignment to expected regions. In order to obtain enough PCR product for cloning, amplifications were per- 
formed in a $50 \mu$ l total reaction volume using 7.5 units of Taq polymerase (Boehringer) and $125 \mathrm{pmol}$ of each primer. PCR conditions were $30 \mathrm{~s}$ at $95^{\circ} \mathrm{C}, 30 \mathrm{~s}$ at the primer-specific annealing temperature and $30 \mathrm{~s}$ at $72^{\circ} \mathrm{C}$ (45 cycles). Amplified DNA was analyzed by electrophoresis on a $2 \%$ agarose gel, stained with ethidium bromide and UV visualized.

Cloning and sequencing. Amplified DNA fragments were excised from the agarose gel and extracted by the QIAEX II kit. DNA fragments were cloned in TOPO TA vector according to the manufacturer's instructions (Invitrogen) and samples were sequenced on a Beckman Ceq 2000 using the Dye-Terminator cycle sequencing kit (Beckman).

\section{RESULTS AND DISCUSSION}

In this paper we present the results of the first genetic analysis ever performed on old seagrass remains. The present analysis and the DNA extraction protocol identified here provide a starting point for future studies on population genetics of extinct seagrass meadows.

Posidonia oceanica meadows are among the few marine systems that, as coral reefs, can remain for millennia in the sediment where their stratigraphy reflects accurately their chronology. In some localities, the matte has been dated to $4000 \mathrm{yr}$ in age (Mateo et al. 1997). Thus, they present a unique opportunity for studying genome evolution over time, historical changes in population dynamics and genetics, and colonization and migration events in the Mediterranean Sea. Here we have shown that DNA is preserved among that material.

The main problems we encountered in the analysis were extraction efficiency, and presence of PCR inhibitors. In our extraction procedure, to minimize DNA loss we did not perform RNA digestion with the additional necessary precipitation, not expecting the presence of preserved RNA in old material. The purification of high molecular weight DNA from agarose gel, instead, reduced the presence of possible contaminants that can inhibit PCR reactions. At the end of the process, almost $300 \mathrm{ng}$ of partially degraded DNA was obtained per gram of old Posidonia tissue, with a concentration only ca. 5 times lower than that obtained from a comparable quantity of living tissue (Fig. 1). In general, the characteristics of old ligneous Posidonia material and its good preservation allowed us to get DNA of a quality and quantity sufficient to analyze species-specific microsatellite markers.

Contamination by foreign DNA from fresh material of the same species or from other species, both in the extraction and in the PCR amplification, is also an issue in the analysis of old DNA. To avoid this problem, we performed a series of negative controls, designed to detect possible contamination in the chemicals or in the equipment used. PCR was performed on our samples, on the negative controls of the extraction, on the negative control of the elution and on a negative control of PCR, in the form of a complete reaction mix without DNA (Fig. 2). The absence of amplification products in negative controls confirms the absence of contamination in the different steps of the whole process.

For a first genetic comparison between recent and old Posidonia oceanica genotypes, we used 3 specific microsatellite markers. Nucleotide sequences of several colonies obtained from cloned PCR fragments confirmed amplification of the expected microsatellite loci. The material sampled in the matte (Sample B) was homozygous for all 3 loci, while the DNA extracted from material preserved at $1.25 \mathrm{~m}$ depth in the soft sediment (Sample A) was heterozygous at the Poc-45 locus (Table 1). The analysis of old material did not detect additional alleles with respect to recent populations analyzed in the Mediterranean basin (Procaccini et al. in press).

Microsatellite loci have been widely used to study relationships among populations. In general, they are characterized by a high mutation rate and are assumed to evolve linearly with respect to the time of disjunc-

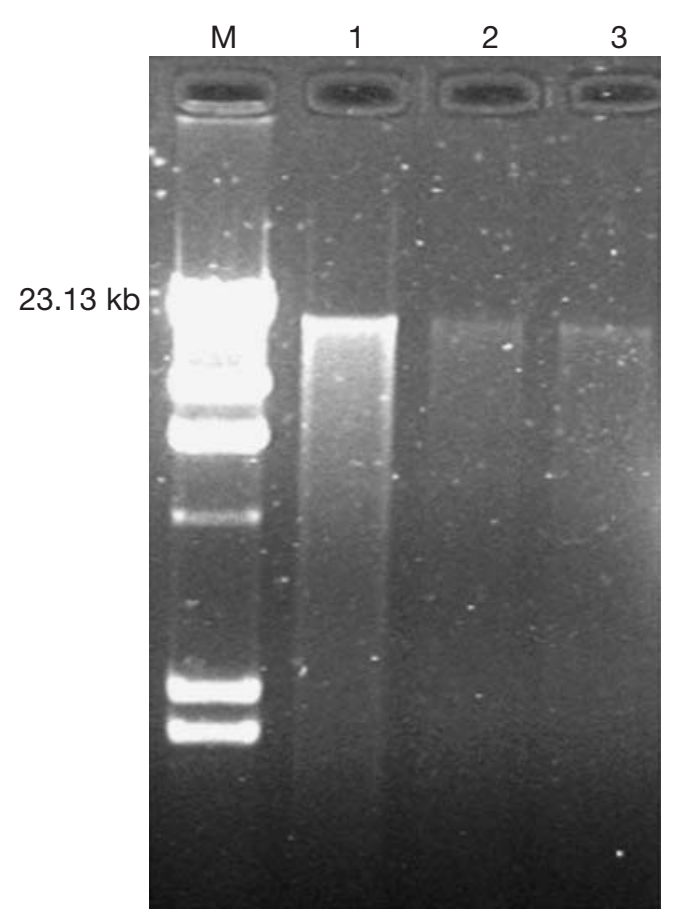

Fig. 1. Comparison between Posidonia oceanica DNA extracted from the same amount of recent (Lane 1) and old material (Sample A: Lane 2 and Sample B: Lane 3). M: molecular weight marker ( $\lambda$-Hind III) 
Table 1. Characteristics of the 2 ancient DNA samples analyzed. The 2 samples were collected (A) in the soft sediment, $1.25 \mathrm{~m}$ below the sediment surface, and (B) in the matte, $60 \mathrm{~cm}$ below the standing shoots. The estimated age, DNA concentration and allele designation are shown. Alleles are expressed in molecular size; for allele code see Procaccini $\&$ Waycott (1998)

\begin{tabular}{|cccccc|}
\hline Samples & $\begin{array}{c}\text { Age } \\
\text { (yr) }\end{array}$ & $\begin{array}{c}\text { DNA } \\
\text { (ng g } \\
\text { of tissue) }\end{array}$ & Poc-5 & Poc-26 & Poc-45 \\
\hline A & 1100 & 320 & $173 / 173$ & $282 / 282$ & $168 / 144$ \\
B & 300 & 320 & $173 / 173$ & $282 / 282$ & $168 / 168$ \\
\hline
\end{tabular}

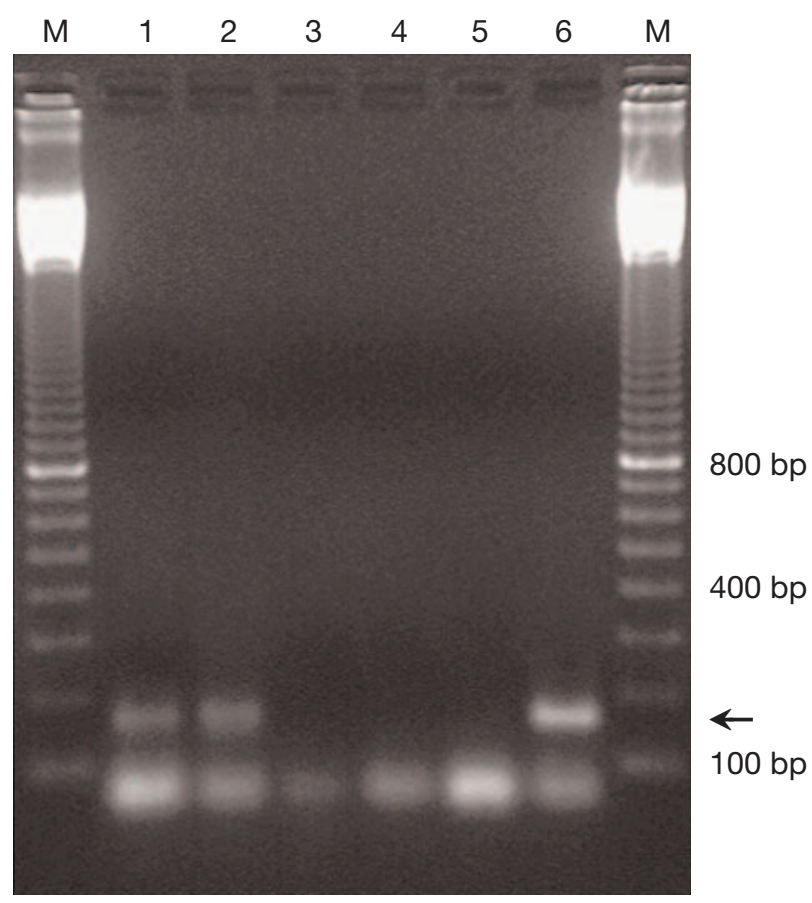

Fig. 2. PCR reactions for $P O C-45$ microsatellite region on Sample A (Lane 1), Sample B (Lane 2), a negative control of the extraction consisting of the extraction buffer poured into the empty mortar (Lane 3), the negative control of the elution (Lane 4), and the negative and positive controls of the PCR reaction (Lanes 5 and 6). Arrow indicates position of amplification products. M: molecular weight marker (adder 100)

tion between 2 different genomes (Goldstein et al. 1994). Both of these characteristics make microsatellites suitable markers for inferring molecular phylogenetic patterns and processes at the intra-specific level. Our results show that microsatellites could be used to trace Posidonia oceanica genetic diversity to within a few thousand years. These regions, in fact, are small enough (150 to $300 \mathrm{bp}$ ) to be amplified also in old and partially degraded DNA. In addition, our data, although limited to only 2 samples, suggest that the mutation rate of the 3 amplified microsatellites is low, probably as a consequence of the slow generation time of this species.

The analysis of old material can help in defining the evolutionary history of Posidonia oceanica in the Mediterranean and may determine whether its dramatic decline (Marbà et al. 1996) is related to a progressive reduction of genetic polymorphism. This can have a significant impact on the definition of strategies to preserve and re-establish this resource along the coasts of the Mediterranean basin.

Acknowledgements. This research was supported by the National Council of Research (C.N.R.), Italy, Target Project on Biotechnology. We would like to thank E. Biffali and the Molecular Biology Service of Stazione Zoologica 'A. Dohrn' for their technical assistance; M. Sacchi of the Geomare Sud (C.N.R., Italy) for the collection and dating of Sample A and M. Lorenti (SZN) for collection of Sample B.

\section{LITERATURE CITED}

Boudouresque CF, Jeudy de Grissac A (1983) L'erbier à Posidonia oceanica en Mediterranée: les interaction entre la plante et le sédiments. J Rech Océanogr 8:99-122

Carbone A, Lirer L, Munno R (1984) Caratteri petrografici dei livelli piroclastici rinvenuti in alcuni gravity cores nel Golfo di Pozzuoli e di Napoli. Mem Soc Geol It 27:195-204

Crouzet A (1984) Contribution à l'etude anatomique des feuilles de Posidonia oceanica (Potamogetonaceae). Variations de la structure le long d'une écaille épaisse. In: Boudouresque CF, de Grissac AJ, Olivier J (eds) International Workshop on Posidonia oceanica Beds. GIS Posidonie, Marseille, Vol 1, p 109-117

Doyle JJ, Doyle JA (1987) A rapid DNA isolation procedure for small quantities of fresh leaf tissue. Phytochem Bull 19:11-15

Dumolin-Lapegue S, Pemonge MH, Gielly L, Taberlet P, Petit RJ (1999) Amplification of oak DNA from ancient and modern wood. Mol Ecol 8:2137-2140

Goldstein DB, Linares AR, Cavalli-Sforza LL, Feldman MW (1994) An evolution of genetic distances for use with microsatellite loci. Genetics 139:463-471

Golenberg EM, Giannasi DE, Clegg MT, Smiley CJ, Durbin M, Henderson D, Zurawski G (1990) Chloroplast DNA sequence from a miocene magnolia species. Nature 344: 656-658

Harlin MM, Thorne-Miller B, Boothroyd JC (1982) Seagrasssediment dynamics of a flood-tidal delta in Rhode Island (USA). Aquat Bot 14:127-138

Hemminga MA, Nieuwenhuize J (1990) Seagrass wrackinduced dune formation on tropical coast (Banc d'Arguin, Mauritania). Estuar Coast Shelf Sci 31:499-502

Larkum AWD, den Hartog C (1989) Evolution and biogeography of seagrasses. In: Larkum AWD, Mc Comb AJ, Shepherd SA (eds) Biology of seagrasses. Elsevier, Amsterdam, p 112-156

Lipkin Y (1979) Quantitative aspects of seagrass communities, particularly of those dominated by Halophila stipulacea, in Sinai (Northern Red Sea). Aquat Bot 7:119-128 
Marbà N, Duarte CM, Cebrian J, Gallegos ME, Olesen B, SandJansen K (1996) Growth and population dynamics of Posidonia oceanica on the Spanish Mediterranean coast: elucidating seagrass decline. Mar Ecol Prog Ser 137:203-213

Mateo MA, Romero J, Perez M, Littler MM, Littler DS (1997) Dynamics of millenary organic deposits resulting from the growth of the Mediterranean seagrass Posidonia oceanica. Estuar Coast Shelf Sci 44:103-110

Mazzella L, Buia MC, Gambi MC, Lorenti M, Russo GF, Scipione MB, Zupo V (1992) Plant-animal trophic relationship in the Posidonia oceanica ecosystem of the Mediterranean Sea: a review. In: John DM, Howkins SJ, Price JH (eds) Plant-animal interaction in the marine benthos. Clarendon Press, Oxford, p165-187

Molinier R, Picard J (1952) Recherches sur les herbiers de Phanérogames marines du littoral méditerranéen français. Ann Inst Océanogr 27:157-234

Pérès JM (1984) La regression des herbies a Posidonia ocean-

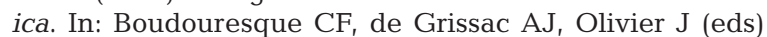
International Workshop on Posidonia oceanica Beds. GIS Posidonie, Marseille, Vol 1, p 445-454

Pérès JM (1985) History of the Mediterranean biota and the colonization of the depths. In: Margalef R (ed) Western Mediterranean. Pergamon Press, Oxford, p 198-232

Procaccini G, Mazzella L (1998) Population genetic structure and gene flow in the seagrass Posidonia oceanica assessed

Editorial responsibility: Otto Kinne (Editor),

Oldendorf/Luhe, Germany using microsatellite analysis. Mar Ecol Prog Ser 169: $133-141$

Procaccini G, Waycott M (1998) Microsatellite loci identified in the seagrass Posidonia oceanica (L.) Delile. J Hered 89: 562-568

Procaccini G, Alberte RS, Mazzella L (1996) Genetic structure of the seagrass Posidonia oceanica in the Western Mediterranean: ecological implications. Mar Ecol Prog Ser 140: $153-160$

Procaccini G, Orsini L, Ruggiero MV, Scardi M (2001) Spatial patterns of genetic diversity in Posidonia oceanica, an endemic Mediterranean seagrass. Mol Ecol 10:1413-1422

Procaccini G, Ruggiero MV, Orsini L (in press) Genetic structure and distribution of microsatellite diversity in Posidonia oceanica over the whole Mediterranean basin. Bull Mar Sci

Rogers SO, Bendich AJ (1985) Extraction of DNA from milligram amounts of fresh, herbarium and mummufied plant tissues. Plant Mol Biol 5:69-76

Rollo F, La Marca A, Amici A (1987) Nucleic acids in mummified plant seeds: screening of twelve specimens by gelelectrophoresis, molecular hybridization and DNA cloning. Theor Appl Genet 73:501-505

Short FT, Wyllie-Echevierra S (1996) Natural and humaninduced disturbance of seagrass. Environ Conserv 23: 17-27

Submitted: March 27, 2001, Accepted: July 5, 2001

Proofs received from author(s): January 29, 2002 